\title{
Morální distres školních psychologů
}

\author{
Jiří Mareš \\ Lékařská fakulta Univerzity Karlovy v Hradci Králové
}

Redakci zasláno 3. 1. 2017 / upravená verze obdržena 2. 5. 2017/

k uveřejnění přijato 4. 5. 2017

\begin{abstract}
Abstrakt: Přehledová studie shrnuje současné domácí i zahraniční poznatky o tom, co prožívá školní psycholog ve vztahové síti školy a jak reaguje na situace, kdy je vystaven sociálním tlakům ze strany vedení školy nebo učitelského sboru či nadřízených školských orgánů. Na psychologa bývá občas vyvíjen nátlak, aby ve „vyšším zájmu" souhlasil s rozhodnutími, která se týkají žáků, kolegů, rodičů i školy, i když takové rozhodnutí není z etického hlediska v pořádku. Přehledová studie věnovaná tomuto tématu má pět částí. První část prezentuje názory odborníků a výsledky dílčích výzkumných sond o etických problémech, s nimiž se setkávají školní psychologové v České republice. Druhá část prezentuje výsledky výzkumů těch etických problémů a etických dilemat, s nimiž se potýkají školní psychologové v USA, Kanadě a ve vybraných evropských zemích. Ve třetí části je charakterizován důležitý pojem této studie - morální distres. Čtvrtá část studie popisuje kvalitativní, kvantitativní a smíšené diagnostické přístupy ke zkoumání eticky náročných situací a zvláštnosti školních psychologů, kteří se v těchto situacích musí rozhodovat. Pátá část shrnuje doporučení o tom, jak morálnímu distresu u školních psychologů předcházet, a pokud už se distres vyskytne, jak v takových případech cíleně intervenovat, aby se jeho negativní dopady snížily.
\end{abstract}

Klíčová slova: školní psycholog, etické kodexy, administrativní tlaky, sociální tlaky, etická dilemata, morální distres, diagnostika, intervence, prevence

\section{Historický kontext}

Psychologická pomoc škole, žákům a učitelům není v několika desetiletích v České republice důležitým tématem. Myšlenka zřídit funkci školního psychologa na středních školách se v Československu objevila už v období první republiky (Stejskal, 1930; Ohera, 1934). Poté se tento směr uvažování o poskytování poradenských služeb psychology přímo na školách u nás na dlouhá desetiletí vytratil. Pozornost odborníků se přesunula na konstituování oboru výchovné poradenství a systému pedagogicko-psychologických poraden. Nové úsilí zřídit profesi školního psychologa se zrodilo na Slovensku na přelomu padesátých a šedesátých let 20 . století a jeho vůdčími osobnostmi byli 
J. Hvozdík a L. Ďurič. Od konce šedesátých let probíhal na Slovensku experiment, který zjištoval, jak funguje působení školního psychologa př́mo na střední škole, se kterými problémy se psycholog setkává a jak by na ně měl být odborně připraven. Souběžně s tím probíhala koncepční, teoretická i výzkumná činnost, která vyvrcholila první propracovanou domácí monografií o školní psychologii (Hvozdík, 1986).

Teprve po roce 1989 však bylo možné dlouho připravované změny naplno realizovat, zejména zásluhou J. Hvozdíka a A. Furmana. Vznikla Asociace školní psychologie ČSFR (1990), později nazvaná Asociace školní psychologie SR a ČR. Na Slovensku se institut školního psychologa dostal do oficiální legislativy v roce 1993 a náplň práce školního psychologa byla specifikována vyhláškou o výchovném poradenství z roku 1996. Situace v České republice byla odlišná a vstup školních psychologů do škol zde byl opožděný. Probíhal jen v omezené míře a neměl zákonnou oporu. Ředitelé českých škol zaměstnávali psychologa ve škole pod různým pracovním zařazením a financovali ho z různých zdrojů; žili však v obavách, že budou obviněni z porušování školské legislativy (Zapletalová, 2001). Jediná zmínka o školním psychologovi se objevila až později, a to $\mathrm{v}$ dokumentu malé právní síly - v Metodickém listu MŠMT o poskytování poradenských služeb na školách a školských zařízeních (Metodický list, 1998). Teprve zákon č. 561/2004 Sb. (tzv. školský zákon) a na něj navazující Vyhláška MŠMT č. 72/2005 Sb. oficiálně konstituovaly institut školského poradenského zařízení.

Tím se školní psycholog stal součástí poradenských služeb poskytovaných školám. Zájemce o detailní výklad vývoje české i světové školní psychologie odkazujeme na přehledové práce Lazarové (2008) a Štecha a Zapletalové (2013).

Dosavadní výzkumy toho, jak funguje školní psycholog v českých základních a středních školách, se týkaly především těchto tří témat (Kavenská, Smékalová, \& Šmahaj, 2011; Mareš, 2016b):

- Školní psycholog jako jedinec: jeho osobnostní charakteristiky, profesní identita a její konstituování, vzdělávací potřeby školního psychologa působícího v praxi;

- profese školního psychologa a role, které plní: jeho sociální role na základní a střední škole, problémy začínajícího školního psychologa, pozice školního psychologa na škole z pohledu učitelů a psychologa samotného, kritická místa profese školního psychologa; 
- vztahová sít školního psychologa: podoba vztahové sítě, vztahy mezi školním psychologem a učiteli z pohledu vedení školy, učitelů a psychologa samotného.

Poněkud opomenuty byly zatím problémy týkající se etických aspektů práce školního psychologa. Cílem této přehledové studie je proto shrnout současné domácí i zahraniční poznatky o tom, co prožívá školní psycholog v situacích, kdy je vystaven sociálním i administrativním tlakům ze strany vedení školy, učitelského sboru, nadř́izených školských orgánů či lokální komunity, kdy je stavěn před etická dilemata. Konkrétně jde o pět cílů: (1) upozornit na možné rozpory mezi dvěma či více etickými principy při rozhodování školního psychologa, (2) předložit výsledky úvah o etických aspektech práce školního psychologa a empirických výzkumných sondách těchto problémů v České republice, (3) shrnout výsledky úvah i empirických výzkumů etických problémů školních psychologů v zahraničí, (4) blíže charakterizovat pojem morální distres a jeho podoby u školních psychologů, (5) přiblížit postupy, jimiž lze diagnostikovat morální distres, a poté charakterizovat cílené intervence, jimiž mu lze předcházet nebo ho alespoň zmírňovat.

Proč právě toto téma? Důvody jsou dva. Američtí odborníci prohlašují: „Přestože administrativní tlaky vedení školy na psychologa, aby se zachoval neeticky, nejsou novým jevem (viz Clement, Zartler, \& Mulick, 1983), publikací na toto téma je dosud velmi málo." (Bocciová, Weisz, \& Lefkowitz, 2016, s. 662). Přitom opakované výzkumy v USA ukazují, že téma nátlaku vedení školy, aby se školní psycholog „V zájmu školy“ zachoval neeticky, se dostaly na první místo situací, s nimiž se psycholog ve škole setkává, a také ho nejvíc trápí (viz např. Jacobová-Timmová, 1999; Dailor \& Jacobová, 2011; Bocciová et al., 2016). Je velmi pravděpodobné, že s širším vstupováním školních psychologů do našich škol budou s uvedenými problémy zápasit také školní psychologové v České republice; měli by být na tuto situaci dobře připraveni.

Dříve, než přistoupíme $\mathrm{k}$ vlastnímu výkladu, připomeneme $\mathrm{v}$ úvodu věcný rozdíl mezi pojmy etika a morálka; tím i rozdíl mezi níže používanými adjektivy „etický“ a „morální“. Etika je chápána jako teoretická disciplína, která studuje obecné hodnoty a principy, jimiž se řídí rozhodování lidí, pokud mají možnost svobodné volby. Etika hodnotí jejich činy z hlediska dobra a zla. Zvažuje, co by jedinec měl dělat, co je správné či nesprávné. Naproti tomu morálka (a tím i morální distres) je pojem mnohem konkrétnější. Vyjadřuje souhrn zásad, které jsou vázány na určité společenství lidí, tj. uvádí, co po svých 
členech daná společnost vyžaduje, a co naopak odmítá. Morálka se nedá vymáhat soudní cestou, ale může být prosazována sociálními tlaky: společnost určitá jednání podporuje či přímo vyžaduje, zatímco jiná zavrhuje a osoby, které se proti morálce proviní, odmítá, někdy i ze společenství vylučuje.

\section{Názory českých odborníků a jejich výzkumné sondy}

Výklad začneme tvrzením, že profesní úskalí institutu školního psychologa nespočívá ani tak v rovině samotných řešených př́ípadů, ale daleko výrazněji v rovině vztahů se subjekty, s nimiž při své odborné práci musí spolupracovat (Štech, 2001). Školní psycholog totiž funguje ve složité vztahové síti školy (Zapletalová, 2001; Lazarová, 2008). Do této specifické sociální sítě patří: jeho vztahy se žáky, třídami, učiteli, vedením školy a rodiči (Keřt, 2014), ale také vztahy s dalšími subjekty mimo školu, např. s pracovníky pedagogicko-psychologické poradny, s pracovníky středisek výchovné péče, s orgány sociálně-právní ochrany dětí, s klinickými psychology a lékaři.

Podle názoru odborníků tyto vztahy přinášejí nejen pozitiva, ale i rizika. Mezi nejčastější patří úskalí ve vztahu k vedení školy, pedagogům, dětem, rodičům, k dalším institucím (Braun, Marková, \& Nováčková, 2014, s. 199). Př́liš bohatá a komplikovaná sít' sociálních vztahů zvyšuje riziko psychologovy závislosti na osobách této sítě, stoupá též riziko přenosu či afektivních komplikací (Štech, 1998). Lze to říci i jinak: školní psycholog se pohybuje v zóně profesněidentitních kompromisủ. Tuto zónu představují situace, kdy psycholog musí dokazovat svou profesní kompetenci, ale zároveň se pokouší vyhnout konfliktům z toho plynoucím. Je jen logické, že ve vztahu k dalším aktérům vzdělávacího procesu (vůči řediteli, učitelům či rodičům) by měl získat dostatečnou autonomii, aby při dojednávání konkrétních zakázek s kteroukoliv z těchto stran nebyl v závislém postavení (Štech, 2001).

Odborná práce v takové instituci, jakou je škola, nastoluje řadu problémů, které Zapletalová souhrnně nazývá kritickými místy profese školního psychologa. $\mathrm{K}$ nejčastějším patří vztah školního psychologa $s$ vedením školy (Zapletalová, 2011). Zátěžovým momentem tohoto vztahu bývá zadávání zakázky ředitelem školy, přičemž její interpretace ředitelem na jedné straně a psychologem na straně druhé se může rozcházet. Postavení psychologa totiž není jednoduché. Za rozsah a kvalitu školních poradenských služeb podle platné vyhlášky sice odpovídá ředitel školy, ale vztah ředitel-školní psycholog není jen vztah typu nadřízený-podřízený, ale také laik-expert (Štech 
\& Zapletalová, 2013). Školní psychologové se na některých školách setkávají s nevhodnými zásahy, ingerencemi do své práce jak ze strany ředitele, tak některých učitelů (Štech, 2001).

Pokud psycholog při své odborné práci odkrývá i tabuizovaná místa ve fungování školy, může se snadno dostat do role „potížisty“ (Zapletalová, 2001). Výzkumná sonda Augustinové však ukázala, že z pohledu učitelů zastávají někteři školní psychologové nejen důležitou roli diplomata, ale také taktika, ba dokonce „chameleóna“, který se pod tlakem vedení školy přizpůsobí tomu, co po něm škola právě vyžaduje (Augustinová, 2015, s. 42).

Podívejme se nyní na některé typické situace, které staví školního psychologa jak před odborná, tak především před etická dilemata. V zásadě se jedná o tři typy situací.

První typ situací se odvíjí od zadání zakázky ze strany školy a jejího vedení. Zde jsou př́klady:

- Na dané škole je žák, který má opakovaně neomluvené absence a porušuje kázeňský řád. Existuje dokonce podezření, že užívá drogy. Jeho rodiče přitom neprojevují zájem o spolupráci se školou. Školní psycholog už se žákem pracuje a uvědomuje si, že většina stížností na daného žáka v podstatě odpovídá skutečnosti, i když učitelé i žákovi spolužáci některé problémy poněkud zveličují. Ředitel žádá psychologa, aby „zařídil“, že tento žák opustí danou školu. Psycholog má k tomu řediteli poskytnout „nějaké podklady“. Př́padně má žáka i jeho rodiče přesvědčit, aby sami „spontánně“ navrhli, že žák přestoupí na jinou školu. Podle ředitele je to v zájmu ochrany jeho spolužáků (Štech \& Zapletalová, 2013, s. 126-127).

Druhý typ situací začíná tím, že školní psycholog musí neustále obhajovat svůj, tj. psychologický pohled na jedince, tř́dy, pedagogické jevy, mezilidské interakce a nesmí se nechat strhnout k laickému pohledu a k jednoduchým laickým interpretacím, i když je zastává většina učitelů a vedení školy.

Školní psychologové konstatují:

- „Na té škole je hrozně těžký si jako psycholog zachovat ten psychologický přístup $\mathrm{k}$ věci, jo. Prostě nenechat se strhnout $\mathrm{k}$ tomu uvažování o dítěti, který občas mají ti učitelé $\mathrm{v}$ ňákých polaritách nebo $\mathrm{v}$ nějakém hodnoticím slova smyslu." (Majdyšová, 2011, s. 51). 
- „Jednou se mi stalo, že na chodbě byl nějaký rozruch, řešila se nějaká někam hozená žákovská knížka. Učitel říkal: ,To tam hodil ten a ten z té třídy.' A v té době to byl průserář, klučina, a já jsem to brala jako hotovou věc. A pak se ukázalo, že ne. A strašně mě to štvalo. A od tý doby si na to dávám bacha, že to fakt může být jinak..." (Soldán, 2012, s. 57).

Třetí typ situací začíná tím, že školní psycholog získá odborným postupem určitá data a vedení školy, učitelé, rodiče či sami žáci ho nutí, aby s těmito daty zacházel (nebo nechal zacházet pracovníky školy) neetickým způsobem. Podívejme se na dva prríklady:

- Za školním psychologem přijde žák, který se mu chce svěřit. Potřebuje s ním probrat svoje problémy, ale nepřeje si, aby o tom kdokoli věděl, a to včetně rodičů a učitelů. Pro individuální práci s nezletilým žákem je ovšem zapotřebí informovaný souhlas jeho zákonných zástupců. Školní psycholog nechce zradit důvěru dítěte a zároveň ví, že o jejich setkávání musí vědět jeho rodiče. Navíc zapojení rodičů bývá někdy nutné i pro samotné řešení problému, s nímž dítě přišlo. $U$ některých dětí to trvá třeba tři i více schůzek, než se s ním psycholog dohodne, že je třeba, aby on jako odborník rámcově informoval rodiče (Augustinová, 2015, s. 51).

- Učitelé se dozvědí, že žák opakovaně navštěvuje školního psychologa. Žádají psychologa, aby jim řekl, s jakým problémem jejich žák za ním chodí, že to přece potřebují vědět. Také školní psycholog mívá pocit, že by o problémech daného žáka měli být nějakým způsobem zpraveni i učitelé (Augustinová, 2015, s. 51). Psycholog tedy řeší dilema, zda informovat učitele, př́íp. $v$ jakém rozsahu a $v$ jaké podobě, aby nejen nezklamal důvěru žáka, ale také informováním učitelů danému žákovi neublížil, nebot' dopředu neví, jak s odbornou informací učitelé naloží. Výzkum Štecha (2001) ukázal, že někteří učitelé zkreslují informace, které od psychologa obdrželi, nebo trvají na zveřejnění jmen žáků, kteří se psychologovi svěřili se svým osobním problémem (např. s abúzem drog), nebo tzv. „řeší problém dítěte“, které má mimořádně obtížné domácí podmínky, způsobem, který ho ponižuje.

Reagování školního psychologa na tři typy výše popsaných situací bývá prověrkou jeho profesionality (Lazarová, 2008).

Bartošová shrnuje názory dotázaných školních psychologů ve svém výzkumu slovy: pro svůj př́istup k žákům, rodičům a učitelům by školní psycholog 
neměl zapadat do běžné hierarchie školy. Má přece svoji specifickou kolonku. Jedna psycholožka jí řekla: „Využívám akorát kodex školního psychologa, jak je na internetu [...] Ten mi přijde, že je to tam zpracovaný. Na tom jsem tady ve škole ukázala, že klient je vlastně nadřazenej organizaci, to tak bylo vždycky. [...] rodič ví, že já jsem s ním. Že nezastupuju školu. To dělá paní ředitelka a třídní učitel. Je to jasně daný." (Bartošová, 2011, s. 69). Citovaná autorka dodává, že školní psycholog se však nemůže zbavit svého spojení se školou, nebot' to z povahy jeho psychologických služeb nejde. Musí však dávat najevo, že není „prodlouženou rukou“ vedení školy ani jen advokátem dětí či soudcem ve sporech.

Činnosti školního psychologa ve škole jsou v České republice vymezeny explicitními standardy (podrobnosti viz Vyhláška č. 72/2005, př́loha č. 1). Vycházejí z odborných kompetencí, jež této profesi přísluší, a z etického kodexu, který musí školní psychologové respektovat. Problémem ovšem je, že život přináší etická dilemata, která jsme popsali výše. V nich se mohou dva i více etických principů dostat do vzájemného rozporu.

V etickém kodexu (Oakland, Goldmanová, \& Bischoff, 1994), který přijala v r. 1994 Asociace školní psychologie SR a ČR za svůj, se v oddíle Profesionální odpovědnost, odstavec 1.2 , uvádí:

Školní psychologové znají školský zákon a příslušné směrnice, vyhlášky, doporučení. Pokud jsou administrativní předpisy a nařízení v rozporu s etickými principy, vyvíjejí školní psychologové upř́mnou snahu tyto neshody a rozdíly odstranit. Pokud v tomto úsilí neuspějí, měli by dát přednost etickým principům.

V odstavci 1.2 se dále píše: „Ochrana blaha žáků a studentů, jejich rodičů, učitelů a pedagogů je pro školní psychology prvořadou záležitostí. Pokud nastane konflikt zájmů, školní psychologové preferují zájmy žáků a studentů.“

Příklad:

Jedna učitelka má výrazně agresivní přístup ke svým žákům. Školní psycholožka o tom ví a snaží se její nevhodný přístup korigovat. Nechce však vstoupit do př́mé osobní konfrontace s danou učitelkou, a proto se sama snaží o zprostředkování pohledu obou stran. Učitelka však žádnou diskusi s dětmi nepřipouští a skutečnost, že psycholožka vybízí žáky, aby řekli svůj pohled, vnímá jako podněcování k osobním útokům, takže konflikt dál eskaluje. Psycholožka si uvědomuje, že učitelka situaci nezvládá, nebot’ má 
strach z propuštění. Způsob jednání dané učitelky s dětmi považuje školní psycholožka za nepřípustný, ale zároveň nechce být tou osobou, která dá podnět k ukončení jejího pracovního poměru. Psycholožka se tedy ocitá před dilematem dvou špatných voleb: pustit se do otevřeného konfliktu s učitelkou, nebo nezasáhnout proti pobuřujícímu jednání se žáky (Soldán, 2012, s. 69).

V etickém kodexu (odstavec 1.2) se rovněž uvádí: „Školní psychologové se vyhýbají situacím, při nichž by docházelo ke konfliktům nebo tajným dohodám, $\mathrm{v}$ jejichž pozadí by stály důvody ekonomické, politické nebo osobní." Tolik z etického kodexu.

Česká psychologická komunita se v roce 2011 dočkala speciální publikace, která je věnována etickým otázkám v psychologii (Weiss, 2011). Potíž je $\mathrm{v}$ tom, že i když spoluautory bylo 22 psychologů, v této publikaci (jak sami autoři přiznávají) chybí kapitoly věnované etickým aspektům psychologické práce s dětmi, chybí etické aspekty pedagogické psychologie a sociální psychologie; a my jen dodáváme - i školní psychologie.

Problémy, s nimiž se školní psycholog setkává, nejsou v čase stále tytéž. Soldán ve své kvalifikační práci upozornil na určitou zastaralost obrazu české školní psychologie, který vytvářely odborné publikace, jež vycházely kolem roku 2000 a krátce po něm. Za posledních 15 let totiž došlo k výraznému posunu v chápání samotného oboru školní psychologie, k propracování jeho obsahu a rovněž ke změně vnímání institutu školního psychologa (jak odbornou veřejností, tak i samotnými školními psychology). Pět nových aspektů lze formulovat takto (modifikovaně podle Soldán, 2012, s. 74-82):

- U nově nastupujícího školního psychologa není začleňování do školního prostředí bezproblémové. K získání prostoru pro odbornou práci však nestačí, aby se vyhnul zaujímání negativních sociálních rolí. Běžně se setkává s nedůvěrou řady učitelů a možným řešením může být trpělivé úsilí o navazování vztahů a naděje, že systematická odborná práce většinu učitelů přesvědčí. Navíc - a to dříve nebylo - nováček někdy přichází do prostředí, které už může mít předchozí zkušenosti s fungováním jiného školního psychologa (at' zkušenosti pozitivní, či negativní), a nováček bude se svým předchůdcem srovnáván.

- Dosavadní obraz školního psychologa v domácí literatuře stavěl na výčtu přínosů, které školní psycholog do školy vnáší. Jinak řečeno, výklad předkládal čtenářum obraz profesionála, u něhož jsou potřebné kompetence 
již přítomny. S výjimkou studie Lazarové (2008) se však nebrala v úvahu skutečnost, že na pozici školního psychologa často nastupují čerství absolventi vysokých škol. Nejsou orientováni ve školním prostředí, neznají lokální mezilidské vztahy a sociální normy dané instituce, musí sladit svá očekávání s očekáváními vedení, učitelů a rodičů. To vše navozuje u začínajících školních psychologů pocit nedostatečné vlastní kompetentnosti.

- V souvislosti s tím se nově vynořuje otázka, jak vypadá a jako dlouho asi trvá základní adaptační období, tedy interval od psychologova nástupu na školu až do doby, kdy se školní psycholog stává plnohodnotným profesionálem. Univerzální hranice zřejmě neexistuje, ale výzkumné sondy naznačují, že spodní hranicí je nejméně jeden školní rok.

- Dalším relativně novým tématem je poskytovatel sociální opory školního psychologa. V literatuře bývá zmiňován obvykle jen ředitel školy, ale novější výzkumy naznačují, že spektrum poskytovatelů opory je a musí být mnohem širší: výchovný poradce, kolegové školní psychologové na jiných školách, odborný metodik pro školní psychology, supervizor aj.

- Učitelé byli v domácí literatuře chápáni jako nepostradatelní prostředníci školního psychologa $\mathrm{v}$ přístupu k dětem, jako ti, kteří mohou jako první zaregistrovat problémy jednotlivcủ či celých tříd. To platí i nadále, avšak nově se vynořuje problematika situací, kdy učitel nemá důvěru ve školního psychologa a řeší vzniklé problémy po svém, tj. „laicky“, či případy, v nichž se vyhrotí konflikt mezi učitelem a školním psychologem.

Načrtnuli jsme aktuální situaci školních psychologů v České republice a nyní je čas podívat se na situaci v některých vyspělých zemích.

\section{Názory odborníků a výzkumy v zahraničí}

Školní psychologie má ve vyspělých západních státech velmi dlouhou tradici, propracovanou legislativu, promyšlené pregraduální i postgraduální vzdělávání školních psychologů, rozsáhlý výzkum, kvalitní časopisy a dobře organizované poskytování služeb přímo na školách (Oakland \& Brue, 1996; Štech \& Zapletalová, 2013 aj.).

Lasser a Klosová (2007) připomínají, že mnozí školní psychologové musí proplouvat systémovými hranicemi své práce, a přitom zažívají konflikt hodnot, přesvědčení, jednotlivých rolí, které zastávají. Etičnost jejich rozhodování 
často ovlivňují sociální faktory, sociální tlaky. Obdobně je tomu i v dalších psychologických profesích. Proto Americká psychologická asociace (APA) už v letech 1952/1953 vypracovala etický kodex psychologů. Ten byl postupně novelizován a v roce 2002 byla vydána zatím poslední, 10. revize. Nešlo jen o lepší formulace a dílčí konsensuální doplnění textu, ale i změny, které se opíraly o empiricky zjištěná data. V roce 1992 totiž dvojice psychologů Pope a Vetterová uskutečnila pro APA výzkum na reprezentativním vzorku členů APA a zmapovala etické problémy, s nimiž se američtí psychologové ve své praxi za poslední rok či dva potýkali. Mezi prvními třemi nejčastějšími byly tyto kategorie: snaha o porušení principu důvěrnosti informací a dodržování mlčenlivosti psychologa (18\%), nejasné, rozporné nebo konfliktní vztahy mezi psychologem a klienty (17 \%), problémy s finančními zdroji, plány, metodami $(14 \%)$.

Podle stejného výzkumného projektu pak v následujících letech proběhly analogické výzkumy v osmi dalších zemích. Z Evropy to byla Velká Británie, Švédsko, Norsko, Finsko, z afrického kontinentu pak Jižní Afrika, z amerického kontinentu Kanada a Mexiko a z australské oblasti Nový Zéland. Výsledky těchto výzkumů později souhrnně zpracovali Pettifor a Sawchuk (2006). Konstatovali, že ve všech sledovaných zemích převládaly dva etické problémy s touto průměrnou prevalencí: snaha o porušení principu důvěrnosti informací a dodržování mlčenlivosti psychologa (25\%) a problém nejasných, podvojných a konfliktních mezilidských vztahů ${ }^{1}$ (14\%).

Také vedení Národní asociace školních psychologů v USA (dále jen NASP) - se důkladně věnuje etickým aspektům práce svých psychologů. První etický kodex přijala zmíněná asociace již v roce 1974 a další revize proběhly v letech 1984, 1992, 1997 a 2000. Zatím poslední revize se uskutečnila v roce 2010 (NASP, 2010).

Inovování etických kodexů však rozhodně nestačí. Důvod je jednoduchý: formulace $\mathrm{v}$ etickém kodexu školního psychologa nedávají návod, jak se zachovat v konkrétní situaci. Kodex obsahuje jen široké abstraktní principy a neřeší do detailu případy, v nichž spolu soupeří nebo se dostávají do přímého

\footnotetext{
V angličtině je tento problém označován zpravidla jako blurred, dual, or conflictual relationships nebo zkráceně dual relationships. V češtině se zatím jeho označování neustálilo. Jednotliví autoři mluví o konfliktu rolí a zájmů (Svoboda \& Klimusová, 2011, s. 177), o porušení hranic terapeutického vztahu s klientem (Smitková, 2011, s. 227), o dvojím vztahu psychologa s klientem či o křížení odborného a běžného kontaktu s klientem (Junová, 2011, s. 312).
} 
konfliktu dva či více etických principů. Text neuvádí a nemůže uvádět situační kontext. Výstižně to formulovali odborníci na lékařskou etiku: znění etických kodexů má jen deklarativní charakter, a tím se podobá znění ústavy - ta také vyžaduje poučenou interpretaci (Benatar \& Singer, 2000). Můžeme jen dodat: $\mathrm{k}$ tomu slouží ve školní psychologii jiné publikace, které ustanovení etického kodexu ilustrují analýzou případových studií z běžné školní praxe - viz např. Koocher a Keithová-Spiegelová (2008); Armistead, Williams a Jacobová (2011).

Jen některé výzkumy se zatím zajímaly o administrativní tlaky vedení školy na psychologa, aby se zachoval neeticky. Budeme je prezentovat $v$ chronologickém pořadí. Jedním z prvních byl výzkum Basela (1990) na výběrovém souboru školních psychologů ze všech oblastí USA. Předkládal jim 25 eticky problematických situací, s nimiž se může psycholog setkat, a požadoval od nich dva typy odpovědí: zda se s tímto problémem za poslední rok při své práci setkali a nakolik se cítí na jeho řešení připraveni. Výzkum ukázal, že míra připravenosti nezávisí na stupni psychologova vzdělání, pohlaví, věku ani na délce praxe. Výzkumná sonda Janna (1991) u školních psychologů organizovaných v NASP také zjistila tlaky školní administrativy na školní psychology. Studie Janna, Hymana a Reinhardta (1992) zaregistrovala sociální nátlak na školního psychologa ze strany supervizorů. Jacobová-Timmová (1999) konstatovala, že psychologem vnímané sociální tlaky vedení školy, aby se angažoval $v$ eticky problematických aktivitách, patří k nejčastějším situacím, $\mathrm{s}$ nimiž se školní psycholog $\mathrm{v}$ praxi setkává. Zjistila toto pořadí: (1) administrativní nátlak na psychologa, aby se zachoval neeticky; (2) diktát vedení školy, aby psycholog použil při diagnostice či hodnocení žáků postupy, které jsou z odborného pohledu nevhodné; (3) nátlak na porušení povinné mlčenlivosti.

Výzkum Heltona, Raye a Bidermana (2000) se ptal školních psychologů a školních speciálních pedagogů v USA, jak by se zachovali oni sami a jak jejich kolegové (školní psychologové a speciální pedagogové) ve čtyřech eticky náročných situacích, kdyby byli pod tlakem vedení školy, které po nich chce, aby jednali - údajně v zájmu školy - neeticky. Výsledky naznačily, že většina aktérů by se asi chtěla zachovat eticky správně, i když míra toho, jak by jednali, závisela na typu popsané situace. Ukázalo se také to, co se dalo čekat: respondenti napsali, že eticky správně by se spíše chovali oni sami, zatímco jejich kolegové jako celek v mnohem menší míře (rozdíl byl statisticky významný). 
Výzkum Heltona a Rayové $(2005,2009)$ identifikoval pět chyb, jichž se školní psychologové dopouštějí, když se rozhodují, kterou strategii volit při tlaku vedení školy, aby se zachovali při své práci neeticky. Jednalo se o tyto chyby psychologů:

- Snaha zbavit se administrativního nátlaku tím, že se psycholog uzavře do své profese, chrání si své teritorium, vyhýbá se kontaktům s vedením školy.

- Snaha přikládat větší váhu osobnímu zájmu než požadavku etického kodexu školního psychologa, který zní: chránit zájmy dítěte a jeho práva; psycholog raději zůstává stranou, nevstupuje do řešení problémů, nekomplikuje si život.

- Zaujetí postoje, že požadavky vedení školy mají přednost před etickou odpovědností psychologa, tj. vyhovění tlaku.

- Dospění k přesvědčení, že je marné vzdorovat tlaku vedení školy, tj. podvolení se.

- Selhání tím, že psycholog při rozhodování, jak se zachovat, vůbec nerozpozná, že jde o eticky závažný problém. Neuvědomí si míru své profesionální odpovědnosti za obranu práv žákủ, jak mu to ukládá etický kodex.

V dalších letech se zřejmě situace př́liš nezměnila. Výzkum Dailora a Jacobové (2011) identifikoval toto pořadí nejfrekventovanějších etických dilemat školních psychologů v USA: (1) administrativní nátlak na psychologa, aby se zachoval neeticky; (2) problémy nevhodných edukačních praktik, které někteří učitelé používají; (3) diktování nevhodných postupů, které psycholog má použít při diagnostice či hodnocení, ze strany vedení školy.

Nejnovější výzkum Bocciové a kol. (2016) u amerických školních psychologů konstatoval, že téměř třetina dotázaných zažila sociální tlak na to, aby se zachovala neeticky. Psychologové např. dostávali pokyn, aby nerealizovali postup, který sami považovali za správný, a naopak, aby souhlasili s rozhodnutím, které bylo pro klienty nevhodné. Školní psychologové, kteří takové situace zažili, udávali vysoký stupeň vyhoření, malou spokojenost s profesí, větší přání odejít ze školy a někteří i tendenci změnit své profesní zaměření.

Bracher a Hingley připomínají tři determinanty psychologova rozhodování: „Etické rozhodnutí [...] je výsledný produkt dynamické rovnováhy, která zahrnuje nejméně tři klíčové prvky: osobní etický postoj daného jedince, 
obecné společenské a kulturní hodnoty té společnosti, v níž psycholog žije, a specifický účel dané organizace, jakož i přesvědčení a hodnoty převládající v této organizaci; to vše opravňuje aktéra k určitému typu chování a dává mu návod, jak postupovat." (Bracher \& Hingley, 2002, s. 82).

\section{$4 \quad$ Pojem morální distres}

Mnohokrát jsme konstatovali, že profesionálové, kteří svou práci berou jako poslání, se občas dostávají do odborně i eticky složitých situací, které nemají jednoznačné řešení, nebot' každá z alternativ je do určité míry z morálního hlediska problematická. Během rozhodování o tom, ke kterému řešení se nakonec přikloní, zažívají psychologové negativní stres, tj. distres. Jak upozorňuje O’Connor (2001), může tím být ohroženo jejich mentální zdraví.

Jedním z typických negativních jevů je tzv. morální distres. S tímto pojmem jako první přišel v roku 1984 odborník na etiku v ošetřovatelství, Američan Andrew Jameton. Definoval ho nejprve takto: „Morální distres vzniká v situacích, kdy jedinec ví, co je správné udělat, ale institucionální překážky činí téměř nemožné jednat tím správným způsobem." (Jameton, 1984, s. 6). Později svou definici upravil a napsal: „Jedinec zažívá morální distres, když dospěje k morálnímu závěru o př́padu, který sám řeší, ale instituce nebo spolupracovníci mu zkomplikují nebo přímo znemožní jednat v duchu tohoto rozhodnutí." (Jameton, 1993, s. 542).

Ukázalo se, že právě definovaný jev se relativně často vyskytuje ve zdravotnictví, především u všeobecných sester, viz např. Austinová a kol. (2005a), ale objevuje se také u lékařů. Byly formulovány zajímavé teorie a vypracovány různě složité modely (přehled viz Mareš, 2016a). Zatím jsme zmínili pouze aplikování tohoto pojmu ve zdravotnictví. Jsme oprávněni ho použít i v dalších profesích? Sám autor tohoto pojmu Jameton nedávno napsal, že užití pojmu morální distres se postupně rozšiřuje a tento pojem je užitečný i v jiných profesích. Ba co více, není už vázán pouze na profese samotné, ale začíná se s ním pracovat i v úvahách o rizicích nových technologií a farmaceutických výrobků pro člověka, o závažných dopadech lidské činnosti na životní prostředí (Jameton, 2013).

Je tedy korektní aplikovat pojem morální distres i ve školní psychologii. Byla to právě Austinová a kol., kteří se jako jedni z mála tímto jevem zabývali nejen u zdravotníků, ale také u psychologů. Morální distres u psychologů definují takto: 
Jedná se o jedincovo reagování v situaci, kdy je přesvědčen, že ví, co by bylo morálně správné učinit, ale nemůže to udělat. Jedinec pocituje morální odpovědnost, uvědomuje si ji, ale ta nevyústí v čin. Absence reálného činu může být způsobena jednak rozpaky, vnitřními zábranami, osobním selháním, jednak vnějšími tlaky, vnějšími překážkami. (Austin et al., 2005b, s. 198)

Ve své studii Austinová se spolupracovníky cituje také definici morálního distresu od Nathanielové z roku 2002:

Morální distres lze charakterizovat jako trápení, trýzeň, až bolest postihující mysl, tělo i mezilidské vztahy. Jde o reagování jedince na situaci, kdy si uvědomuje morální problém, svoji morální zodpovědnost a dospívá $\mathrm{k}$ morálnímu závěru o tom, co by bylo třeba učinit. Avšak - v důsledku reálných nebo jen pocitovaných nátlaků - se nakonec spolupodílí na postupu, který sám vnímá jako morálně špatný.

Podle Jametona (1993) existují dva základní typy morálního distresu:

1) prvotní morální distres (initial moral distress), který navozuje u člověka negativní emoce (např. vztek, úzkost). Jedinec čelí institucionálním překážkám a konfliktům se spolupracovníky či nadřízenými. Jedná se o aktuální konflikt, kdy se rozhoduje mezi tím neudělat nic, nebo nějak jednat, a pak vybírá $\mathrm{z}$ řady alternativ.

2) Pozdější, reaktivní morální distres (reactive moral distress) má jinou podobu. Jedinec se v duchu k celé situaci vrací a obvykle se trápí tím, co udělal, nebo tím, co neudělal a udělat měl.

V běžném provozu školy se stává, že se morální distres školních psychologů čas od času opakuje a dopady onoho časově oddáleného, reaktivního distresu se kumulují. Jinak řečeno, jedinec se nevyrovná s jednou zátěžovou situací úplně, bezezbytku. Obvykle po ní zůstane v jeho psychice negativní stopa, pocit nesprávného jednání, vlastního selhání. Pokud se takové situace vracejí, pak se negativní zážitky a jejich zbytky, rezidua, hromadí, narůstají. Podle Webstera a Baylise (2000, s. 208) je morální reziduum to, co každý $\mathrm{z}$ nás $\mathrm{v}$ životě nese $\mathrm{s}$ sebou, když tváří $\mathrm{v}$ tvář morálnímu distresu zradil sám sebe nebo připustil, že se bude podílet na něčem, s čím nesouhlasil, a tím se zpronevěřil svým zásadám. Model takových morálních dopadů je schematicky znázorněn na obr. 1. 


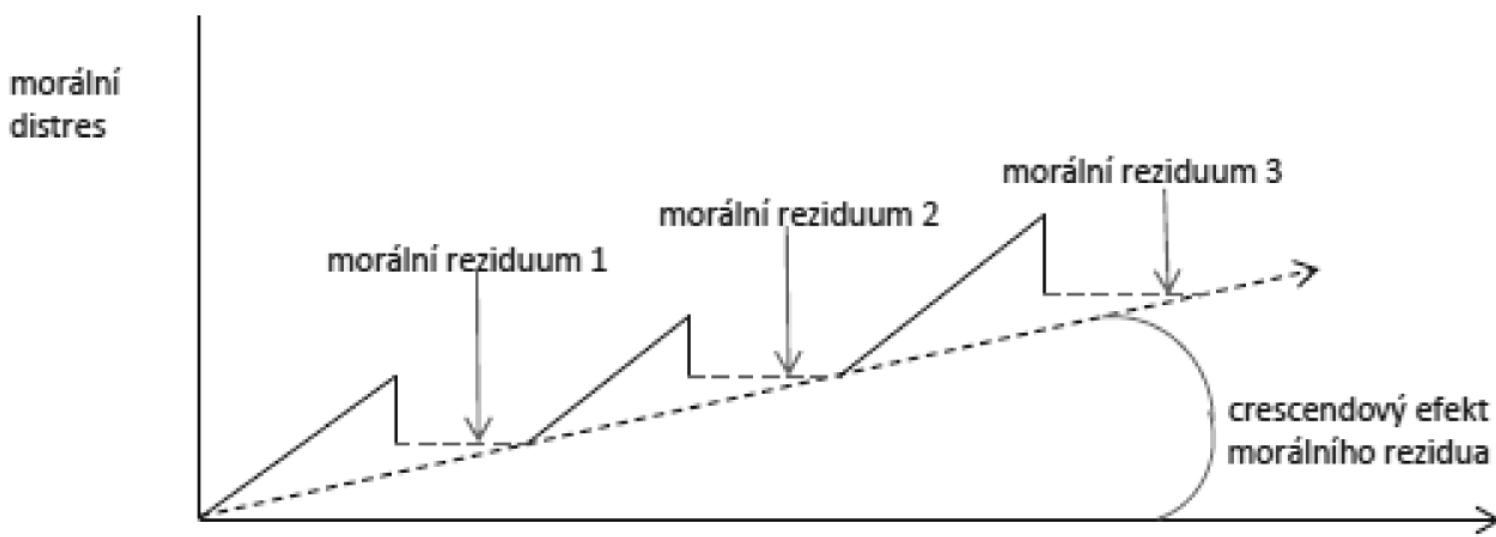

běžicí čas

Obrázek 1. Dlouhodobý efekt opakovaného morální distresu: narůstání morálních reziduí. Upraveno podle Epsteinové a Hamricové (2009, s. 332).

Obrázek 1 ukazuje, jak se postupně kumulují negativní dopady těch morálních distresů, které jedinec zažívá. Zbytků po každém morálním distresu postupně přibývá a negativně působí na psychiku jedince. Autorky modelu si pro označení mechanismu dlouhodobých kumulativních dopadů morálního distresu vypůjčily hudební termín: navrhly výraz crescendový efekt. Ten naznačuje, že nejde jenom o postupné narůstání, ale také o zesilování intenzity a stoupání účinku.

\section{Diagnostika morálního distresu}

Dříve, než se budeme věnovat jednotlivým diagnostickým přístupům, se musíme zastavit u predmětu diagnostiky, tj. zodpovědět otázku, co všechno se těmito postupy obvykle zjištúuje.

a) Situace, události. Ve školní psychologii se nejvíce pozornosti zatím věnuje eticky závažným situacím, které musí školní psycholog řešit. Zjištujú se typy situací, četnost jejich výskytu, náročnost na rozhodování psychologa, vztah k etickým standardům, viz např. Pope a Vetterová, (1992); Flyová a kol. (1997); Bennettová (2008); Mendesová a kol. (2016). V tomto směru se diagnostika ve školní psychologii shoduje s diagnostikou eticky náročných situací, které se zjištují ve zdravotnictví.

b) Zvláštnosti psychologa. Ve školní psychologii se diagnostika věnuje některým zvláštnostem jedince-psychologa. Zkoumají se např. jeho znalosti 
etického kodexu a etických standardů, míra jeho připravenosti z vysoké školy na řešení etických problémů, které přináší práce školního psychologa (Basel, 1990; Fly et al., 1997), jeho odolnost, nezdolnost vůči zažívanému stresu (Crossonová, 2015), jeho zranitelnost až oslabenost ${ }^{2}$ (O'Connor, 2001; Mahoney \& Morris, 2012), jeho etická kompetentnost (Monahon, 2012). Tyto charakteristiky jedince se ve zdravotnictví téměř nestudují.

c) Profesionální, pracovní distres. V dostupné literatuře o školní psychologii jsme nenašli výzkumy, které by př́mo, nezprostředkovaně diagnostikovaly míru zažívaného morálního distresu. Spíše se setkáme s výzkumy a diagnostickými nástroji, které popisují dopady široce pojatého pracovního distresu, přičemž řešení etických problémů tvoří obvykle jen jeden z mnoha stresorů (viz např. Wise, 1985; O'Connor, 2001; Cruz \& Melo, 1996; Gersch \& Teum, 2005; Almeide, 2013; Crosson, 2015).

d) Sociální aspekty prožívaného distresu. Ve školní psychologii se badatelé zajímají o to, nakolik je rozhodování psychologa ovlivněno známými sociálněpsychologickými jevy, viz dotazník (Klose, Lasser, \& Reardon, 2012, tab. 1). Ve zdravotnické sféře bývají tyto vlivy spíše zahrnovány prŕmo do diagnostiky morálního distresu.

e) Etické klima na daném pracovišti. U školních psychologů jsme nalezli pouze jeden výzkum, který se cíleně zajímal o specifika etického klimatu na školách; autory jsou Huhtalaová a Feldt (2016). Ve zdravotnických výzkumech se toto téma objevuje častěji.

Nyní můžeme přejít k podrobnějšímu výkladu. Je známo, že tradiční dělení rozlišuje diagnostické přístupy na kvalitativní, kvantitativní a smíšené. Nebudeme je zde prezentovat $\mathrm{v}$ podobě výčtu používaných nástrojů, ale ponecháme je v kontextu, v němž se $s$ nimi pracuje. Zpravidla nejde o poradenský kontext, o supervizi či krizovou intervenci, ale jedná se o výzkumný kontext. Závěry získané určitým diagnostickým postupem neslouží (až na výjimky) k psychologické práci s jedincem, ale k práci s větší skupinou

$\mathrm{V}$ angličtině je tento problém označován zpravidla jako professional impairment nebo zkráceně impairment. $\mathrm{V}$ češtině se zatím jeho označování neustálilo. Jednotliví autoři mluví o „neschopnosti“, z níž plyne povinnost neprovozovat praxi, když je negativně ovlivněna psychologova schopnost či soudnost, včetně dočasných problémů (Weiss, 2011, s. 321), nebo o „osobních problémech“, které interferují s pracovní aktivitou psychologa (Weiss, 2011, s. 80). 
psychologů. Závěry vyúst’ují v opatření, která se týkají odborné komunity, at' už je definována teritoriálně, institucionálně, zkušenostně atp.

Těžiště diagnostiky je v kvalitativním přístupu. V České republice kvalitativně orientované výzkumy přímo zaměřené na morální distres školních psychologů zatím neexistují. Podívejme se na několik zahraničních př́íladů.

Pope a Vetterová (1992) uskutečnili korespondenční výzkum u 679 amerických psychologů, členů APA. Instrukce zněla: „Popište nám několika slovy, př́p. rozved'te podrobněji událost, která se stala Vám nebo Vašim kolegům během posledního roku nebo dvou a představovala etický problém nebo etickou výzvu." Celkem 545 psychologů ( $80 \%$ ) z oněch oslovených napsalo, že nějakou eticky složitou událost $\mathrm{v}$ tomto období zažilo. Respondenti uvedli 703 takových situací. Obsahová analýza dospěla k 23 kategoriím. První tři nejčastější kategorie jsme už zmínili výše: (1) snaha o porušení principu důvěrnosti informací a dodržování mlčenlivosti psychologa, (2) nejasné, rozporné nebo konfliktní vztahy mezi psychologem a klienty; (3) problémy s finančními zdroji, plány, metodami. Čtvrtá v pořadí se týkala etických problémů, které souvisejí se školním prostředím, výukovými dilematy, se zájmem o výcvik (8\%), pátou kategorii tvořily soudní aspekty práce s klientem (5\%). Tímto výzkumem se inspirovalo mnoho školních psychologů, před časem i Lindénová a Rådeströmová (2008), které zkoumaly etické problémy školních psychologů ve Švédsku a v Jižní Africe.

Flyová a kol. (1997) provedli korespondenční výzkum u garantů akreditovaných studijních programů psychologie v USA i v Kanadě. Oslovili 243 garantů a vyplněné podklady dostali od 75 garantů (návratnost $31 \%$ ). Badatelé uváděli, že se inspirovali technikou kritických událostí podle Flagana (1954). Instrukce pro garanty zněla: „Uved’te tři události, v nichž Vaši studenti během svého vzdělávání a praktického výcviku porušili etické hranice. Popište samotnou událost, zasad'te ji do potřebného kontextu (kdy se to odehrálo, kde se to dělo, kdo byli aktéři atd.); přibližte, co se přesně dělo, jak vyučující reagoval na porušení hranic. Zdůvodněte, proč si myslíte, že v daném případě šlo o etický problém." Obsahová analýza identifikovala 8 kategorií událostí: porušení důvěrnosti informací, překračování profesionální hranice, plagiátorství nebo zkreslování údajů, nedbání prospěchu klienta, porušení závazného postupu s etickými dopady, překročení odborných kompetencí, porušení integrity osobnosti (lhaní, vyhýbání se práci, předstírání kvalifikace, kterou nemají). 
Bennettová (2008) zadávala elektronicky dotazník o etických dilematech, která zažívají pedagogičtí/školní psychologové ve Velké Británii. Dotazník obsahoval 8 převážně otevřených otázek a požadoval popsat nejméně jednu dilematickou situaci, kterou psycholog musel ve škole řešit. Na žádost o vyplnění dotazníku vstřícně zareagovalo 120 pedagogických/školních psychologů. Získané odpovědi byly analyzovány pomocí zakotvené teorie. Autorka si položila čtyři výzkumné otázky:

1) Jak psychologové pracující ve školách chápou adjektivum „etický“? Nejčastější odpovědi byly: snažit se, aby druzí lidé byli v pohodě, a nečinit nic, co by je poškozovalo; dodržovat dohodnutá pravidla a jednat podle nich; respektovat lidská práva.

2) Zažívají psychologové v práci etické dilema? Pokud ano, jak často? Etická dilemata zažívá 99,2\% dotázaných psychologů, a to: 12,7\% denně; $18,6 \%$ několikrát týdně; 28,0 \% pravidelně, ale ne každý týden; $26,3 \%$ málokdy, tj. párkrát za rok; 13,6\% velmi vzácně; 0,8 \% nikdy.

3) Co je podstatou těchto dilemat? Zvažování alternativ a vyvažování zájmů; respektování důvěrnosti získaných informací; problém odlišných hledisek a odlišných diskursů; bytí „mezi dvěma mlýnskými kameny“.

4) Čím se psychologové řídí při řešení těchto dilemat? Preferují zájmy dítěte či dospívajícího; řídí se křest'anskou etikou; pro svá rozhodnutí nemají žádné filozofické nebo náboženské zdůvodnění; volí postup, který je v souladu $\mathrm{s}$ jejich politickým přesvědčením nebo s myšlenkou sociální spravedlnosti.

Portugalský tým vedený Mendesovou (2016) získal korespondenčně údaje od 477 školních psychologů. Zadaná instrukce zněla: „Popište tři eticky náročné situace, které jste zažili při své odborné práci během posledního roku." Celkem 274 psychologů (57 \%) napsalo, že nějakou eticky náročnou událost v tomto období zažilo. Uvedli 441 takových situací, jejichž obsahová analýza dospěla k 6 kategoriím: problém se zajištěním soukromí a důvěrnosti informací; problémy spojené s psychologickou praxí a intervenováním; komplikované vztahy s jinými odborníky; problémy související s psychodiagnostikou a hodnocením, s informovaným souhlasem a autodeterminací; problémy se závěry vyšetření a s dokumentací.

Bennettová (2008) zmiňuje ve své práci užitečnost přístupu, který se osvědčil při zkoumání morálního distresu u finských učitelů, také pro psychology. 
Jedná se o případovou studii, v níž je profesionál působící ve škole vyzván, aby si po určitou dobu vedl deník, který by zachytil eticky náročné situace, s nimiž se při své práci se žáky setkává. Badatel pak vede s tímto profesionálem rozhovor o zažitých situacích, o kontextu, v němž vznikaly, o postupu, který profesionál zvolil pro jejich řešení atd. (Tirri, 1999). Zatím však zmíněný postup nebyl u školních psychologů využit.

Můžeme tedy shrnout. $V$ dostupné literatuře jsme našli dva základní postupy, které se dají použít u školních psychologů. První staví na stručném písemném popisu eticky náročných situací, s nimiž se psychologové ve škole setkávají a jež musí řešit; poté následuje analýza takových textů a hledání obecnějších kategorií, typů těchto situací. S těmi se potom pracuje u dalších psychologů i studentů psychologie. Nezř́íka tvoří základ pro konstruování dotazníků. Druhou možností je prípadová studie: profesionál si vede podrobný deník, v němž popisuje nejen etická dilemata samotná, ale i jejich genezi, průběh, vyústění a dopady. Odborník potom tyto zápisky analyzuje, s profesionálem diskutuje a společně hledají řešení. Nenašli jsme ryze kvalitativní přístup, který by stavěl na individuálních rozhovorech se školními psychology nebo na diskusi v ohniskové skupině.

Těžiště diagnostiky je v kvantitativním přístupu. Reprezentují ho především dotazníky. Respondenty bývají nejčastěji školní psychologové v praxi, studenti psychologie, jejich vyučující, příp. další zaměstnanci školy.

Zde je prŕíklad. Bocciová se spolupracovníky (2016) zadávala mimo jiných nástrojů i dotazník, který předkládal osm situací, v nichž školní psycholog zažívá tlak nadřízených, aby se zachoval neeticky. Dotazník byl rozeslán 600 náhodně vybraným školním psychologům (po 12 z každého státu USA). Výzkumu se nakonec zúčastnilo 291 školních psychologů. V rámci volných odpovědí se měli vyjádřit, zda se $s$ takovou situací sami na své škole setkali, zda byl tlak vedení provázen hrozbami a zda jednání psychologa, které po nich vedení školy požadovalo, bylo v rozporu s celostátní legislativou nebo legislativou daného státu USA. První tři nejfrekventovanější tlaky byly tyto: stáhnout doporučení ke speciálně-pedagogickým službám pro daného žáka či žáky, nebot' by to bylo pro školu příliš drahé; provést neadekvátní vyšetření žáka nebo neadekvátní intervenci; odsouhlasit přeřazení žáka do jiné speciálně-pedagogické kategorie tak, aby to bylo pro školu výhodnější.

Přehled dostupných zahraničních dotazníků přináší tabulka $1 \mathrm{v}$ příloze tohoto článku. 
Dotazníková šetření u školních psychologů obvykle zjištují, zda psycholog určitou situaci nebo etické dilema vůbec zažil, a pokud ano, jak často se taková událost podle jeho zkušeností vyskytuje. Obdobný výzkum ve zdravotnictví přidává ještě jedno hledisko, a tím je intenzita zažívaného distresu při rozhodování jedince, co má v takovém případě udělat (viz např. Hamricová, Borchers, \& Epstein, 2012; de Veerová et al., 2013). Tento aspekt u naprosté většiny výzkumů ve školní psychologii chybí.

Smíšený přístup kombinuje kvalitativní a kvantitativní přístup s cílem zeslabit jejich nevýhody a zesílit jejich výhody.

Výzkum Hildebrandové a kol. (1995) se uskutečnil u 46 kanadských školních psychologů. Náhodným výběrem byli rozděleni do dvou skupin. Se skupinou 14 psychologů byl proveden polostrukturovaný rozhovor, zbývající skupina vyplňovala elektronicky zaslaný dotazník. Samotný rozhovor měl pět etap. Nejprve badatelé vysvětlili psychologovi účel výzkumu. Pak ho požádali, aby uvedl jeden př́klad eticky problematické situace ze své psychologické praxe ve škole, a vybídli ho, aby si pročetl 4 ukotvující viněty (byly totožné s vinětami v dotazníku). Psycholog měl v rozhovoru u každého př́ípadu identifikovat jádro etického problému a formulovat svůj názor na řešení. Ve třetí etapě byl dotázán na chápání př́ídavného jména „etický“. Ve čtvrté etapě byla zjišt'ována psychologova osobní data a pátou etapu tvořil debrífing. Rozhovor byl přepsán do protokolu a text byl podroben obsahové analýze.

Pokud jde o elektronicky rozesílaný dotazník, měl tři části. V první části zjištoval profesní dráhu školního psychologa. Zajímal se rovněž o strukturu jeho činnosti na škole a jeho zkušenosti s poradenskou činností. Druhá část dotazníku obsahovala 7 ukotvujících vinět: žádost rodičů, aby psycholog dítě vyšetřil, aniž o něm má další informace, a aby zprávu o vyšetření nedal k dispozici škole; problém, že psycholog ví, co by bylo nejvhodnější pro dané dítě, ale to žije s rodiči v odlehlé lokalitě, nemůže nikam daleko dojíždět a rodiče ani nemají prostředky na typ doporučovaných služeb; situace doporučení žáka do soukromého zařízení, nikoli státní školy, kdy psycholog detailně diskutuje s rodiči dříve, než to probere s vedením kmenové školy; jednání o dítěti s rodičem, který pozbyl svá práva k dítěti; ředitel žádá na psychologovi, aby mu poskytl údaje, které jsou důvěrné a neměly by být dávány k dispozici laikům. 
Výzkum Tryonové (2001) proběhl u 80 garantů studia psychologie na různých univerzitách $\mathrm{v}$ USA. V kvalitativní části měli popsat nejvýše tři události, v nichž - podle názoru garantů - studenti nedodrželi etické standardy profese nebo porušili (během posledních pěti let) etický standard výukového pracoviště. Zadání znělo: „Popište blíže tuto událost; uved'te, čím připoutala Vaši pozornost; zda jste se o ní zmínili v kursu etiky; vyličte, jak nakonec událost dopadla." V kvantitativní části byli garanti studia požádáni, aby odhadli, jak problematické jsou asi etické názory jejich studentů týkající se 10 eticky složitých situací (např. dodržení povinné mlčenlivosti, udržení profesních hranic při psychologické práci s klientem, ohlášení neetického chování kolegy atd.). Svůj odhad měli vyjádřit pomocí pětistupňové škály.

\section{Možná prevence a možné intervence}

Nestačí jen morální distres u školních psychologů zjistit, ale je třeba na základě diagnostikovaného stavu jednat. S oporou o zahraniční zkušenosti představíme tři přístupy: jeden je jednodušší a prakticky zaměřený, druhý je systémový a sází především na prevenci, třetí se opírá o psychologovu sebepéči.

První př́istup předložili odborné veřejnosti Koocher a Keithová-Spiegelová (2008). Doporučený postup pro školní psychology shrnuli do osmi bodů:

1) Popište přesně problémovou, dilematickou situaci.

2) Definujte potenciální etické či právní souvislosti.

3) Hledejte v odborné literatuře etická/právní doporučení, jak se zachovat. Pokud existují, použijte je. Pokud ne, konzultujte problém s odborníky.

4) Posud'te práva, povinnosti, odpovědnost, prospěch a blaho všech zúčastněných subjektů.

5) Sepište seznam těch alternativ řešení, které podle Vás připadají v úvahu.

6) Zvažujte možné důsledky každé alternativy. Posud'te průběžné, krátkodobé i dlouhodobé dopady každého řešení.

7) Shromážděte důkazy o tom, které rozdílné důsledky přináší každá alternativa rozhodnutí, jež by byla přijata.

8) Rozhodněte se pro jednu alternativu a přijměte svoji odpovědnost za toto rozhodnutí. Monitorujte vynořující se důsledky svého rozhodnutí. 
Druhý přístup má charakter oficiálního dokumentu NASP a věnuje se otázce, jak může školní psycholog předcházet tlaku vedení, aby se „ve vyšším zájmu" zachoval neeticky, a jak může psycholog reagovat, pokud se takové tlaky vyskytnou. Doporučené strategie uvádíme modifikovaně podle Bocciové (2015, s. 2-3):

- Edukujte vedení školy o Vaší odpovědnosti jako školního psychologa a také o etických požadavcích, které stanovují Vaše profesionální povinnosti. Vedení si nemusí uvědomovat ustanovení, jimiž se musíte řídit, a Vy tím můžete předejít příp. budoucím nedorozuměním či konfliktům.

- Vysvětlete vedení školy, že Vaše úsilí být advokátem žáků je motivováno snahou ochránit daný školní obvod před možnými stížnostmi rodičů na diskriminační praktiky školy vůči některým žákům, nebo dokonce snahou ochránit školu před soudním řízením.

- Snažte se citlivě vnímat potřeby instituce, která Vás zaměstnává. Vedení školy je vázáno určitými limity a je vystaveno reálným tlakům (např. má limitovaný rozpočet). Rozhodnutí vedení se často odvíjí od legitimních zájmů školy jako celku.

- Pochopte, že statut školy a př́íslušná školská legislativa nepožadují po škole, aby poskytovala žákům tu nejlepší výchovu a vzdělání nebo ideální vzdělávací proces. Měla by však nabízet dětem s postižením individuální vzdělávací plán a měla by všem žákům poskytovat rovné vzdělávací př́ležitosti.

- Usilujte o rozvíjení pozitivních pracovních vztahů s vedením školy, s učiteli a dalšími pracovníky školy. Má-li k Vám ředitel pozitivní vztah a schvaluje-li Vaše počínání, bude mnohem ochotněji akceptovat Vaše odborná doporučení.

- Důkladně se informujte o detailech rozpočtu školy a dalších finančních zdrojích, o nichž škola uvažuje. I když tyto detaily nejsou typickou součástí psychologova popisu práce, Vaše znalost povinných výdajů školy a dostupných finančních zdrojů může být cenná tehdy, když potřebujete argumentovat, abyste mohl získat pro školu nějaké speciální služby nebo když požadujete další prostředky na svou činnost.

- Není vhodné zaujmout k názoru vedení školy na řešení nějakého problému jednoduchý postoj typu „to není možné“ nebo „tohle já neudělám“. 
Např. pokud se vedení školy chce zbavit žáka, který je diagnostikován jako žák mající poruchu chování (aniž proběhne celý předepsaný proces), navrhněte vedení školy alternativy. Třeba: přidělíme mu asistenta, který s ním bude pracovat individuálně, dokud neproběhne legislativou stanovený postup. Psycholog musí být tvořivý a uvažovat tak, aby byly saturovány potřeby žáků a současně bylo vyhověno požadavkům vedení školy.

- Edukujte rodiče o tom, na které služby mají jejich děti nárok. Informujte rodiče, kde se dozvědí o svých právech.

- Přihlédněte $\mathrm{k}$ tomu, že Vám kolegové mohou poskytnout instrumentální i emoční oporu. Školní psychologové na jiných školách, výchovný poradce, sociální pracovníci i učitelé mohou být Vašimi „etickými spojenci“. Navíc školní psychologové mají možnost konzultovat své etické problémy s jinými profesionály.

- Pamatujte si, že jste to Vy sám, kdo je nakonec zodpovědný za svá stanoviska a za své jednání. Argument, že člověk prostě jen plnil př́́kazy a nařízení, není přijatelnou obranou pro chování, které porušuje ustanovení etického kodexu a právních předpisů.

- Pokud je třeba, měly by do sporu vstoupit odbory. Zejména v případech, kdy je administrativní nátlak provázen hrozbou, že bude následovat zastrašování či šikanování. Školní psycholog si musí vést detailní dokumentaci o případech, kdy vedení školy použilo zastrašování či nátlaku $\mathrm{k}$ tomu, aby prosadilo své neetické, nebo dokonce protiprávní pokyny nebo př́kazy.

- Je dủležité, aby školní psycholog rozpoznal, kdy jeho úsilí být advokátem žáků a jeho snaha nastolit harmonickou spolupráci jsou marné, nevedou k žádoucímu výsledku, a dokonce směřují k poškození jeho mentálního zdraví. Školní psycholog si v určitém okamžiku musí připustit, že se u něj objevují příznaky vyhoření, a musí hledat cesty, jak zvládnout profesionálně stres, který pramení $\mathrm{z}$ konfliktů s vedením školy. V takových případech to znamená, že by měl změnit pracoviště, přejít na jinou školu, kde může sladit požadavky vedení školy s profesionální etikou a se svým hodnotovým systémem.

Třetí přístup staví na péči školního psychologa o sebe sama, na předcházení problémům a udržování si svého mentální zdraví. Autoři se inspirovali 
myšlenkami pozitivní psychologie a vypracovali soubor postupů, co dělat a jak to dělat. Zájemce odkazujeme na systém, který je označován jako MPPP - Mindfulness-based Positive Principles and Practice a vytvořili ho Wiseová, Hersh a Gibsonová (2012).

\section{Závěry a výhledy}

Pro práci školních psychologů jsou nepochybně důležité oficiální etické dokumenty, které jim dávají jistá vodítka pro jejich rozhodování. Měli bychom však rozlišovat tři úrovně obecnosti (Mareš, 2013): (1) etické principy, které vyjadřují základní etická stanoviska formulovaná v etickém kodexu a jsou východiskem pro nižší úrovně, ale nejsou vymahatelné (např. respektování osobních práv a důstojnosti člověka, beneficence, tj. dbání prospěchu klienta, zodpovědnost, spravedlnost atd.); (2) etické standardy, které specifikují profesionálně správné jednání; jsou závazné, vymahatelné a v př́ípadě jejich nedodržení bývají profesní komunitou sankcionovány (nepřekračování kompetencí psychologa, zajištění soukromí a důvěrnost informací, odborně správná psychodiagnostická činnost, vedení dokumentace atd.); (3) etická doporučeni ${ }^{3}$ (ethical guidelines), která shrnují odborné rady, návody, doporučení, jak postupovat, jak se správně rozhodovat a $\mathrm{k}$ jakým důsledkům může rozhodnutí vést.

Právě popsané oficiální dokumenty jsou ovšem jen rámcovým vodítkem. Je třeba, aby jejich obsah byl správně interpretován a v praxi korektně aplikován. Naše přehledová studie se soustředila na jediný tematický okruh, totiž na etická dilemata, jež vyplývají ze sociálních tlaků na školní psychology, aby „přihlédli“ k zájmům školy, učitelů, rodičů, vlivných osob v dané komunitě, nikoli k zájmům žáka, k jeho dobru. Jinak řečeno, aby se zachovali neeticky, což může u řady z nich vyvolat morální distres, at' už těmto tlakům vyhoví, nebo se jim vzeprou.

Je třeba zdůraznit, že ve školní psychologii se termín morální distres - na rozdíl od výzkumů ve zdravotnictví - prakticky nepoužívá. Toto téma je u školních psychologů obvykle chápáno ve spojení se specifickou složkou jejich pracovního stresu (occupational stress, work-related stress), kterou jsou eticky náročné situace spojené s řešením etických dilemat. Bývají vyvolány sociálními a administrativními tlaky na psychologa, aby jednal neeticky (social and administrative pressures to act unethically).

\footnotetext{
Viz např. CPA (2007): Professional Practice Guidelines for School Psychologists in Canada.
} 
Ve vyspělých zemích (zejména v USA) se zmíněný problém stává naléhavým pro svou frekventovanost i pro své převážně negativní důsledky. Vždyt’ nerozpoznaný a neřešený morální distres může mít trvalé dopady na člověka, at' už se jedná o oblast somatickou, emoční či spirituální. Jak píší Austinová a kol. (2005b, s. 199), profesionálové, jakými jsou školní psychologové, mohou zažívat pocit vyhoření či mohou zvažovat odchod z dané školy nebo z profese vủbec.

Z celého dosavadního výkladu $\mathrm{v}$ naší studii by se mohlo zdát, že morální distres je vždy jenom škodlivý jev. Není tomu tak. Dokonce jsme oprávněni (podle Corley, 2002) v některých případech mluvit i o pozitivním efektu morálního distresu. Podle Hardingové (1980) už samo vyprávění jedince o zažitém morálním distresu svědčí o tom, že tomuto jedinci není lhostejné, jaké morální klima na jeho pracovišti převládá. Jedinec dává najevo své vysoce morální hodnoty a snahu poskytnout svým klientům co nejlepší služby, bojuje za zlepšení dosavadního neutěšeného stavu. Může posloužit svým kolegům jako pozitivní vzor. Exaktní výzkumy těchto pozitivních jevů nás ovšem teprve čekají.

V naší studii jsme podali přehled dosavadních výzkumů o administrativních a sociálních tlacích na psychologa, aby se zachoval neeticky, a uvedli jsme diagnostické možnosti, které se nabízejí. Ve srovnání s výzkumem ve zdravotnické sféře má ovšem školní psychologie co dohánět zejména při studiu morálního distresu samotného. Zatím se zaměřuje spíše na situační kontext distresu, jakož i na mediátory a moderátory, které ho ovlivňují, nikoli na samotný distres. Kromě diagnostických problémů jsme se při výkladu věnovali také možné prevenci a intervenčním postupům. Kudy se má odborná práce vydat dál?

V úvodu celé studie jsme konstatovali, že česká školní psychologie věnovala značnou pozornost tématu identity školního psychologa (např. Štech, 1998; Bartošová, 2011; Ušáková, 2013), tedy otázce, kdo je školní psycholog a jaké role ve škole může plnit. Úplně stranou pozornosti zůstala druhá, možná důležitější otázka, která trápí školní psychology v zahraničí už desítky let: Kdo je klientem školního psychologa? Výborný přehled hledání odpovědi na tuto otázku podala nedávno Fisherová (2014). Ukázala, že už v roce 1955 se ptal Cutts: „Je klientem žák jako jednotlivec nebo škola jako organizace?“ V roce 1996 probíhající debatu ještě zkomplikovali White a Loos, když upozornili, že může existovat i kategorie „skrytý klient“ (hidden client). Fisherová nakonec 
dospěla k jednoduché odpovědi. Otázka je postavena chybně. Měl by v ní být plurál, protože klientů bývá obvykle více než jeden. ${ }^{4}$ Odtud ovšem plyne, že pokud školní psycholog poskytuje služby více skupinám klientů, ocitá se logicky v situacích, kdy se loajalita k jednomu a obhajování jeho zájmů dostává do etického konfliktu s loajalitou k druhému klientovi či druhým klientům a hájením jejich zájmu; viz např. McNamarová a Jacobová (2008) nebo úvod etického kodexu NASP (2010). Některé z těchto etických konfliktů bývají velmi intenzivní, např. zájem dítěte versus přání rodičů versus představa školy; tlak vedení školy na neetické jednání psychologa versus jeho snaha dodržet etický kodex.

Pokud psychologové takovým tlakům neodolají, zpravidla se potom trápí. Ocitají se totiž na šikmé ploše či na „kluzkém svahu“. Pro svá neetická řešení hledají dodatečně ospravedlnění. Zde jsou některé příklady (cit. podle Honzák, 2011, s. 67-68):

- Když to vedoucí [...] chce, tak to nemůže být neetické.

- Pokud to etický kodex nezakazuje, tak to nemůže být neetické.

- Neporušuji přece zákon, tak to nemůže být neetické.

- Pokud to dělají také ostatní, tak to nemůže být neetické.

- Pokud nemám v úmyslu někoho poškodit, tak to není neetické.

- Dokud někdo všeobecně uznávaný jasně neprokáže, že by to mohlo někoho poškodit, nemůže to být neetické.

- Není to neetické, pokud mohu s čistým svědomím rríci: Co jiného jsem mohl dělat?! Každý na mém místě by udělal totéž. Byl jsem mezi dvěma mlýnskými kameny. Dělal jsem to i dřív a bylo to $\mathrm{v}$ pořádku. Jsem jenom člověk!

Honzák doplňuje zahraniční zkušenosti vlastním, pro náš případ varujícím pseudoargumentem: „Za neetické není možné považovat jednání, které proběhlo pod stresem. Každý soudný člověk přece ví, jak stres ovlivní každé rozhodnutí, za které pak člověk nemůže nést plnou zodpovědnost." (Honzák, 2011, s. 68). Je to jasný př́klad „etického alibismu“.

Co tedy máme dělat, abychom těmto nepř́iznivým jevům předcházeli, nebo alespoň jejich výskyt snižovali? Cesty jsou přinejmenším tyto: zlepšit

4 Dodáváme sami několik př́íkladů: žák, žáci, třídy, rodiče, učitel, učitelé, vedení školy. 
pregraduální přípravu psychologů nejen důkladnějším vysvětlováním obsahu etických kodexů, ale i diskutováváním se studenty o etických dilematech, která je čekají, a hledáním vhodných strategií, jak na ně reagovat. Vždyt’ platí to, co připomíná H. Junová (2011, s. 315): „Eticky se nezačneme chovat jen díky tomu, že se naučíme Etický kodex."

Bude třeba vydat sbírku př́padových studií, $\mathrm{v}$ níž by byly popsány a rozebrány typické situace, do nichž se začínající i zkušení psychologové dostávají, a kde by byly doporučeny účinné strategie řešení. Je potřebné rozběhnout empirický výzkum morálních dilemat školních psychologů a výsledky výzkumů publikovat. Až doposud jde v naprosté většině o jednorázové, tj. transverzální výzkumy. Jediná longitudinální studie, kterou jsme našli, je portugalská a její autorka Almeidová (2013) v ní sledovala psychology v praxi s odstupem deseti let.

Bude potřebné téma morálních dilemat zařadit do programu odborných konferencí i do dalšího vzdělávání psychologů. Neméně důležité je zajistit školním psychologům, aby eticky náročné problémy mohli konzultovat s metodiky, supervizory a specialisty, včetně právníků. Je čas inovovat etický kodex českých školních psychologů, aby odpovídal současnému stavu poznání i novým výzvám, jak se to dělá ve vyspělých zemích.

To vše, co jsme právě uvedli, je v zájmu našich žáků, jejich rodičů, učitelů, lepšího fungování psychologických služeb na školách i v zájmu samotných školních psychologů.

\section{Literatura}

Almeida, H. (2013). A longitudinal study about stress, burnout and coping. International Journal of Human Resource Studies, 3(2), 109-125.

Armistead, L., Williams, B. B., \& Jacob, S. (2011). Professional ethics for school psychologists: A problem-solving model casebook. Bethesda: National Association of School Psychologists.

Augustinová, K. (2015). Začínající školní psycholog - kvalitativní výzkum procesu jeho pracovního začlenění (Diplomová práce). Olomouc: Filozofická fakulta UP.

Austin, W., Lemermeyer, G., Goldberg, L., Bergum, V., \& Johnson, M. S. (2005a). Moral distress in healthcare practice: The situation of nurses. HealthCare Ethics Committee Forum, 17(1), 33-48.

Austin, W., Rankel, M., Kagan, L., Bergum, V., \& Lemermeyer, G. (2005b). To stay or to go, to speak or stay silent, to act or not to act: Moral distress as experienced by psychologists. Ethics \& Behavior, 15(3), 197-212. 
Bartošová, M. (2011). Profesní identita školního psychologa (Diplomová práce). Praha: Pedagogická fakulta UK v Praze.

Basel, K. (1990). Ethical dilemmas confronting school psychologists. Student work. Paper 320. Omaha: University of Nebraska. Dostupné z http://digitalcommons.unomaha.edu/cgi/ viewcontent.cgi?article $=1326 \&$ context $=$ studentwork

Benatar, S. R., \& Singer, P. A. (2000). A new look at international research ethics. British Medical Journal, 321(7264), 824-826.

Bennett, P. (2008). An investigation into educational psychologists' views of and experiences in ethical decision-making (Disertační práce). Sheffield: University of Sheffield.

Boccio, D. E. (2015). Preventing and resisting administrative pressure to practice unethically. Dostupné z https://www.nasponline.org/standards-and-certification/professional-ethics

Boccio, D. E., Weisz, G., \& Lefkowitz, R. (2016). Administrative pressure to practice unethically and burnout within the profession of school psychology. Journal of Applied School Psychology, 32(4), 313-328.

Bracher, D., \& Hingley, P. (2002). Ethical maturity and organisational health: Some implications for educational psychology services. Educational \& Child Psychology, 19(1), 81-96.

Braun, R., Marková, D., \& Nováčková, J. (2014). Praktikum školní psychologie. Praha: Portál.

Clement, D. B., Zartler, A. S., \& Mulick, J. A. (1983). Ethical considerations for school psychologists in planning for special needs children. School Psychology Review, 12(4), 452-456.

Colnerud, G. (1995). Etik och praktik i läraryrket. En empirisk studie av lärares yrkesetiska konflikter i skolan. Stockholm: HLS Förlag.

Corley, M. (2002). Nurse moral distress: A proposed theory and research agenda. Nursing Ethics, $9(6), 636-650$.

CPA. (2007). Professional practice guidelines for school psychologists in Canada. Ontario: Canadian Psychological Association.

Crosson, J. P. (2015). Moderating effect of psychological hardiness on the relationship between occupational stress and self-efficacy among Georgia school psychologists (Disertační práce). Minneapolis: Walden University.

Cruz, J. F., \& Melo, B. M. (1996). Stress e "burnout" nos psicólogos: Desenvolvimento e características psicométricas de instrumentos de avaliação. Relatório de investigação não publicado. Braga: Universidade do Minho.

Cutts, N. E. (Ed). (1955). School psychologists atmid-century. Washington: American Psychological Association.

Dailor, A. N., \& Jacob, S. (2011). Ethically challenging situations reported by school psychologists: Implications for training. Psychology in the Schools, 48(6), 619-631.

De Veer, A. J., Francke, A. L., Struijs, A., \& Willems, D. L. (2013). Determinants of moral distress in daily nursing practice: A cross sectional correlational questionnaire survey. International Journal of Nursing Studies, 50(1), 100-108.

Epstein, E. G., \& Hamric, A. B. (2009). Moral distress, moral residue, and the crescendo effect. Journal of Clinical Ethics, 20(4), 330-342.

Fisher, M. A. (2014). Why „Who is the client?” is the wrong ethical question. Journal of Applied School Psychology, 30(3), 183-208.

Flagan, J. C. (1954). The critical incident technique. Psychological Bulletin, 51(4), 327-359. 
Fly, B. J., van Bark, W. P., Weinman, L. Kitchener, K. S., \& Lang, P. R. (1997). Ethical transgressions of psychology graduate students: Critical incidents with implications for training. Professional Psychology: Research and Practice, 28(5), 492-495.

Gersch, I., \& Teuma, A. (2005). Are educational psychologists stressed? A pilot study of educational psychologists' perceptions. Educational Psychology in Practice, 21(3), 219-233.

Hamric, A., Borchers, C., \& Epstein, E. (2012). Development and testing of an instrument to measure moral distress in healthcare professionals. American Journal of Bioethics Primary Research, 3(2), 1-9.

Harding, S. (1980). Value laden technologies and the politics of nursing. In S. J. Sprecker \& S. Gadow (Eds.), Nursing: Images and ideals (s. 49-75). New York: Springer Publishing.

Helton, G., \& Ray, B. (2005). Strategies school practitioners report they would use to resist pressures to practice unethically. Journal of Applied School Psychology, 22(1), 43-65.

Helton, G., \& Ray, B. (2009). Administrative pressures to practice unethically: Research and suggested strategies. Ethical Human Psychology and Psychiatry, 11(2), 112-119.

Helton, G., Ray, B., \& Biderman, M. (2000). Responses of school psychologists and special education teachers to administrative pressures to practice unethically: A national survey. Special Services in the Schools, 16(1/2), 111-134.

Hildebrand, D., Saklofske, D. H., Von Baeyer, C. L., \& Yackulic, R. A. (1995). Ethical decision-making in professional consultative practice: A school psychology perspective. McGill Journal of Education, 30(3), 239-256.

Honzák, R. (2011). Některé základní otázky psychologické etiky. In P. Weiss (Eds.), Etické otázky $v$ psychologii (s. 53-73). Praha: Portál.

Huhtala, M., \& Feldt, T. (2016). The path from ethical organisational culture to employee commitment: Mediating roles of value congruence and work engagement. Scandinavian Journal of Work and Organizational Psychology, 1(1), 3.

Hvozdík, J. (1986). Základy školskej psychológie. Bratislava: SPN.

Chevalier, N. E., \& Lyon, M. A. (1993, April). A survey of ethical decision-making among practicing school psychologists. Příspěvek prezentovaný na Annual Convention of the National Association of School Psychologists, Washington, USA.

Jacob-Timm, S. (1999). Ethically challenging situations encountered by school psychologists. Psychology in the Schools, 36(3), 205-217.

Jameton, A. (1984). Nursing practice: The ethical issues. Upper Saddle River: Prentice Hall.

Jameton, A. (1993). Dilemmas of moral distress: Moral responsibility and nursing practice. AWHONN's Clinical Issues in Perinatal and Women's Health Nursing, 4(4), 542-551.

Jameton, A. (2013). A reflection on moral distress in nursing together with a current application of the concept. Journal of Bioethical Inquiry, 10(3), 297-308.

Jann, R. (1991). Research indicates employers pressure members to act unethically. NASP Communique, 20(4), 11-12.

Jann, R., Hyman, I., \& Reinhardt, J. (1992). The consequences of supervisory pressure to act unethically: A national survey. Př́spěvek prezentovaný na National Association of School Psychologists Convention, Nashville, USA.

Junová, H. (2011). Kultivace etiky psychologické práce - úkol pro mezinárodní spolupráci i pro české psychology. In P. Weiss (Ed.), Etické otázky v psychologii (s. 301-316). Praha: Portál. 
Kavenská, V., Smékalová, E., \& Šmahaj, J. (2011). Výzkum v oblasti školní psychologie v ČR. E-psychologie, 5(4), 55-67. Dostupné z http://e-psycholog.eu/pdf/kavenska-etal.pdf

Keřt, R. (2014). Kritická místa profese školních psychologů (Diplomová práce). Olomouc: Filozofická fakulta UP.

Koocher, G. P., \& Keith-Spiegel, P. (2008). Ethics in psychology and the mental health professions: Standards and cases. New York: Oxford University Press.

Lasser, J., \& Klose, L. M. (2007). School psychologists' ethical decision making: Implications from selected social psychological phenomena. School Psychology Review, 36(3), 484-500.

Lazarová, B. (2008). Školní psychologie v České republice po roce 1989. Československá psychologie, 5(52), 480-492.

Lindén, E., \& Rådeström, J. (2008). Ethical dilemmas among psychologists in Sweden and South Africa. Linköpin: Linköping University. Dostupné z http://www.diva-portal.org/smash/ get/diva2:117336/FULLTEXT01.pdf

Mahoney, E. B., \& Morris, R. J. (2012). Practicing school psychology while impaired: Ethical, professional, and legal issues. Journal of Applied School Psychology, 28(4), 338-353.

Majdyšová, M. (2011). Pozice školního psychologa ve vztahových rámcích školy: z pohledu školního psychologa a učitele (Diplomová práce). Brno: Filozofická fakulta MU.

Mareš, J. (2013, srpen). Etické aspekty diagnostické a intervenční práce školního psychologa. Referát na konferenci Diagnostika a intervenční postupy ve školní psychologii. Zlín.

Mareš, J. (2016a). Moral distress: Terminology, theories and models. Kontakt, 18(3), 137-144.

Mareš, J. (2016b). Školní psycholog jako výzkumník: zamyšlení nad možnostmi. Pedagogická orientace, 26(1), 5-23.

Klose, L. M., Lasser, J., \& Reardon, R. F. (2012). Effects of social psychological phenomena on school psychologists' ethical decision-making: A preliminary empirical analysis. Educational Psychology in Practice, 28(4), 411-424.

McNamara, K., \& Jacob, S. (2008). Making ethical decisions in challenging situations. Bethesda: National Association of School Psychologists. Dostupné z https://www.google.cz/?gws_ $\mathrm{rd}=\mathrm{ssl} \# \mathrm{q}=$ making+ethical+decisions+in+challenging+situations

Mendes, S. A., Nascimento, I. M., Abreu-Lima, I. M., \& Almeida, L. S. (2016). A study of the ethical dilemmas experienced by school psychologists in Portugal. Ethics \& Behaviour, 26(5), 1-20.

Metodický list $\mathrm{k}$ poskytování poradenských služeb na školách a školských zařízeních č.j. 13 409/98-24. (1998). Věstník MŠMT, 54(5), 13-19.

Monahon, L. W. (2012). An analysis of the self-reported ethical competencies of school psychologists across the continuum of professional development (Disertační práce). Philadelphia: Philadelphia College of Osteopathic Medicine, Department of Psychology'.

NASP (2010). Principles for professional ethics. Dostupné z https://www.nasponline.org/ standards-and-certification/professional-ethics

Nathaniel, A. (2002). Moral distress among nurses. Ethics and human rights issue update 2002 spring, 1(3), 3-8.

Oakland, T., \& Brue, A. W. (1996). Mezinárodní perspektivy školní psychologie. Pedagogika, 46(5), 24-31.

Oakland, T., Goldmanová, S., \& Bischoff, H. (1994). Etické normy práce školního psychologa. Učitelské noviny, 102(27), 17-18. 
O'Connor, M. F. (2001). On the etiology and effective management of professional distress and impairment among psychologists. Professional Psychology: Research and Practice, 32(4), 345-350.

Ohera, F. (1934). Funkce školního psychologa. Znojmo: Jahoda.

Pettifor, J. L., \& Sawchuk, T. R. (2006). Psychologists' perceptions of ethically troubling incidents across international borders. International Journal of Psychology, 41(3), 216-225.

Pope, K. S., \& Vetter, V. A. (1992). Ethical dilemmas encountered by members of the American Psychological Association. American Psychologist, 47(3), 397-411.

Smitková, H. (2011). Etická dilemata v psychoterapii a psychologickém poradenství. In P. Weiss (Ed.), Etické otázky v psychologii (s. 221-228). Praha: Portál.

Stejskal, C. (1930). O školního psychologa. Praha: Grégr a syn.

Soldán, J. (2012). Autobiografická zkušenost konstruování profesní identity školního psychologa $v$ kontextu vztahového rámce školy (Diplomová práce). Brno: Fakulta sociálních studií MU.

Svoboda, M., \& Klimusová, H. (2011). Etické aspekty psychodiagnostické činnosti. In P. Weiss (Ed.), Etické otázky v psychologii (s. 163-196). Praha: Portál.

Štech, S. (1998). Profesní identita školního psychologa. Pedagogika, 48(3), 257-264.

Štech, S. (2001). Sonda do profese školního psychologa v ČR. Pedagogika, 51(1), 47-55.

Štech, S., \& Zapletalová, J. (2013). Úvod do školní psychologie. Praha: Portál.

Tirri, K. (1999). Teachers' perceptions of moral dilemmas at school. Journal of Moral Education, 28(1), 31-47.

Tryon, G. S. (2001). School psychology students' beliefs about their preparation and concern with ethical issues. Ethics \& Behavior, 11(4), 375-394.

Ušáková, V. (2013). Proměny profilu profesní identity školního psychologa za posledních deset let (Diplomová práce). Praha: Pedagogická fakulta UK.

Voňková, H., Papajoanu, O., \& Bendl, S. (2016). Aplikace metody ukotvujících vinět v pedagogickém výzkumu: přehled literatury a metodologická doporučení. Pedagogická orientace, 26(3), 537-559.

Vyhláška č. 72/2005 Sb. o poskytování poradenských služeb ve školách a školských poradenských zařízeních (v aktuálním znění z r. 2016). Praha: MŠMT.

Webster, G., \& Baylis, F. (2000). Moral residue. In S. B. Rubin \& L. Zoloth (Eds.), Margin of error: The ethics of mistakes in the practice of medicine (s. 217-232). Hagerstown: University Publishing Group.

Weiss, P. (2011). Etické otázky v psychologii. Praha: Portál.

White, L. J., \& Loos, V.E. (1996). The hidden client in school consultation: Working from a narrative perspective. Journal of Educational and Psychological Consultation, 7(2), 161-177.

Wise, P. S. (1985). School psychologists' rankings of stressful events. Journal of School Psychology, 23(1), 31-41.

Wise, E. H., Hersh, M. A., \& Gibson, C. M. (2012). Ethics, self-care and well-being for psychologists: Reenvisioning the stress-distress continuum. Professional Psychology Research and Practice, 43(5), 487-494.

Zákon č. 561/2004 S. o předškolním, základním, středním, vyšším odborném a jiném vzdělávání (školský zákon). (2004). Dostupné z http://www.zakonyprolidi.cz/cs/2004-561

Zapletalová, J. (2001). Co dělá školní psycholog? Kritická místa profese. Pedagogika, 51(5), 37-46. 


\section{Autor}

Prof. PhDr. Jiří Mareš, CSc., Lékařská fakulta Univerzity Karlovy, Šimkova 870, 50003 Hradec Králové, e-mail: mares@lfhk.cuni.cz

\section{School psychologists' moral distress}

Abstract: The review summarizes current Czech and international research findings on what a school psychologist experiences in a relationship network of a school and how they react to situations in which they are subject to social pressure by the management, the teachers or the external cooperating bodies. A school psychologist can sometimes be pressured to agree with decisions concerning pupils, colleagues, parents and the school "for the greater good", even though such decisions might be ethically disputable. The review is divided into five parts. The first one presents experts' opinions and research findings concerning ethical issues encountered by school psychologists in the Czech Republic. The second part focuses on research findings about ethical issues and dilemmas of school psychologists in the USA, Canada and selected European countries. The third part deals with the central concept of this paper, i.e. moral distress. The fourth part describes the qualitative, quantitative, and mixed diagnostic approaches to investigating ethically charged situations and the specific characteristics of school psychologists who have to deal with them. The fifth part summarizes the recommendations on how to prevent moral distress of school psychologists and on how to mitigate its negative effects.

Keywords: school psychologist, ethical codes, administrative pressures, social pressures, ethics dilemmas, moral distress, assessment, intervention, prevention 


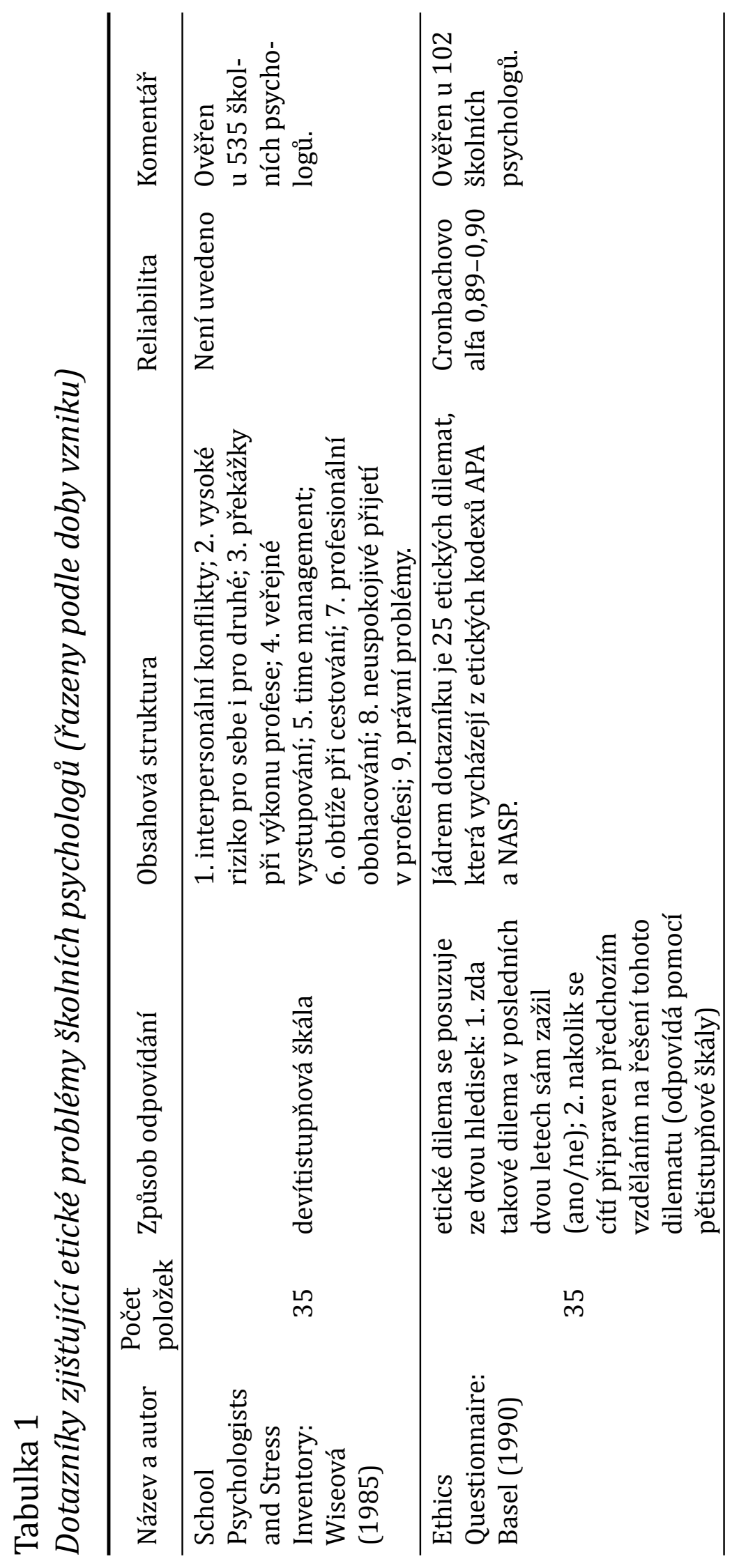




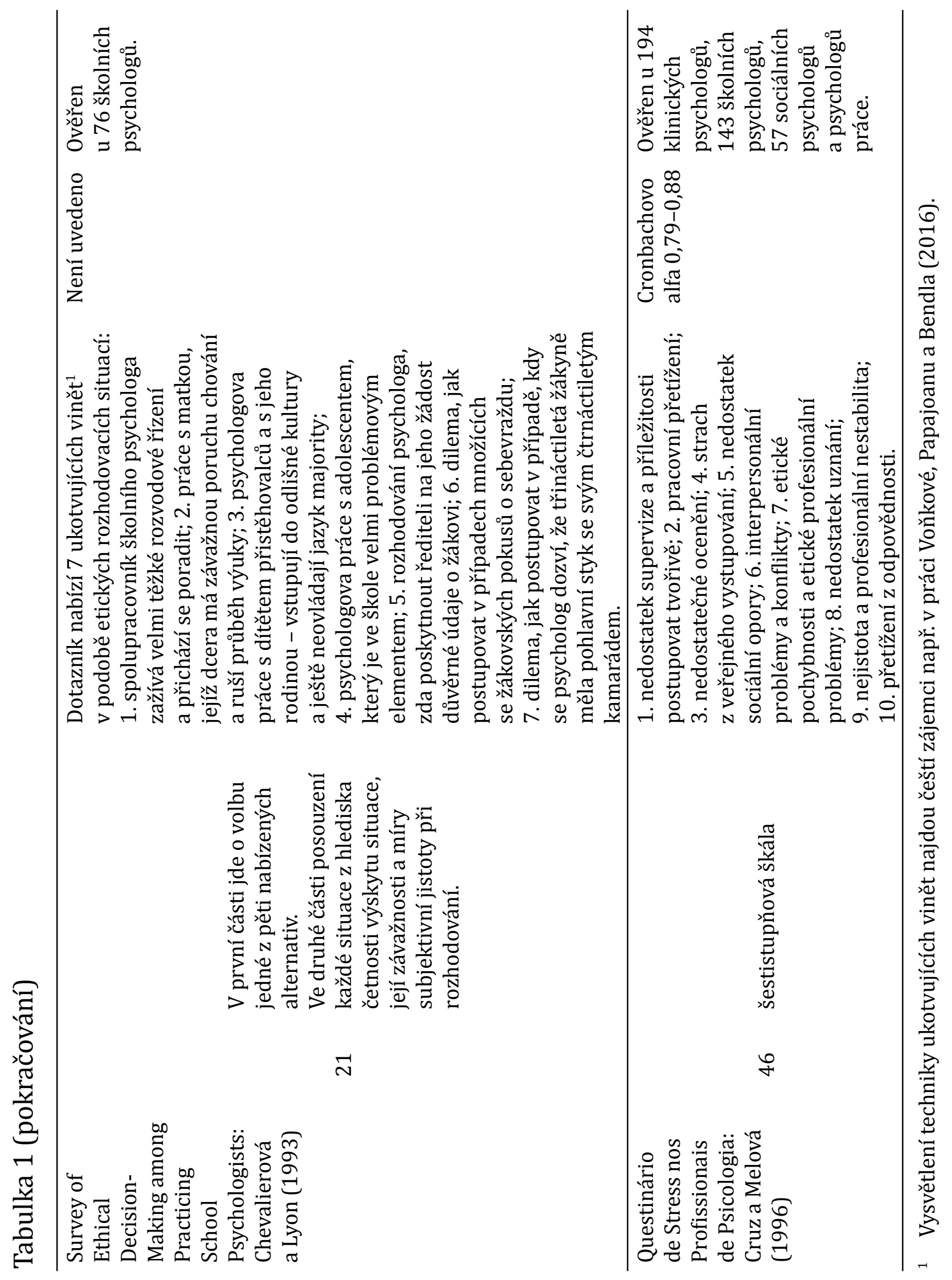




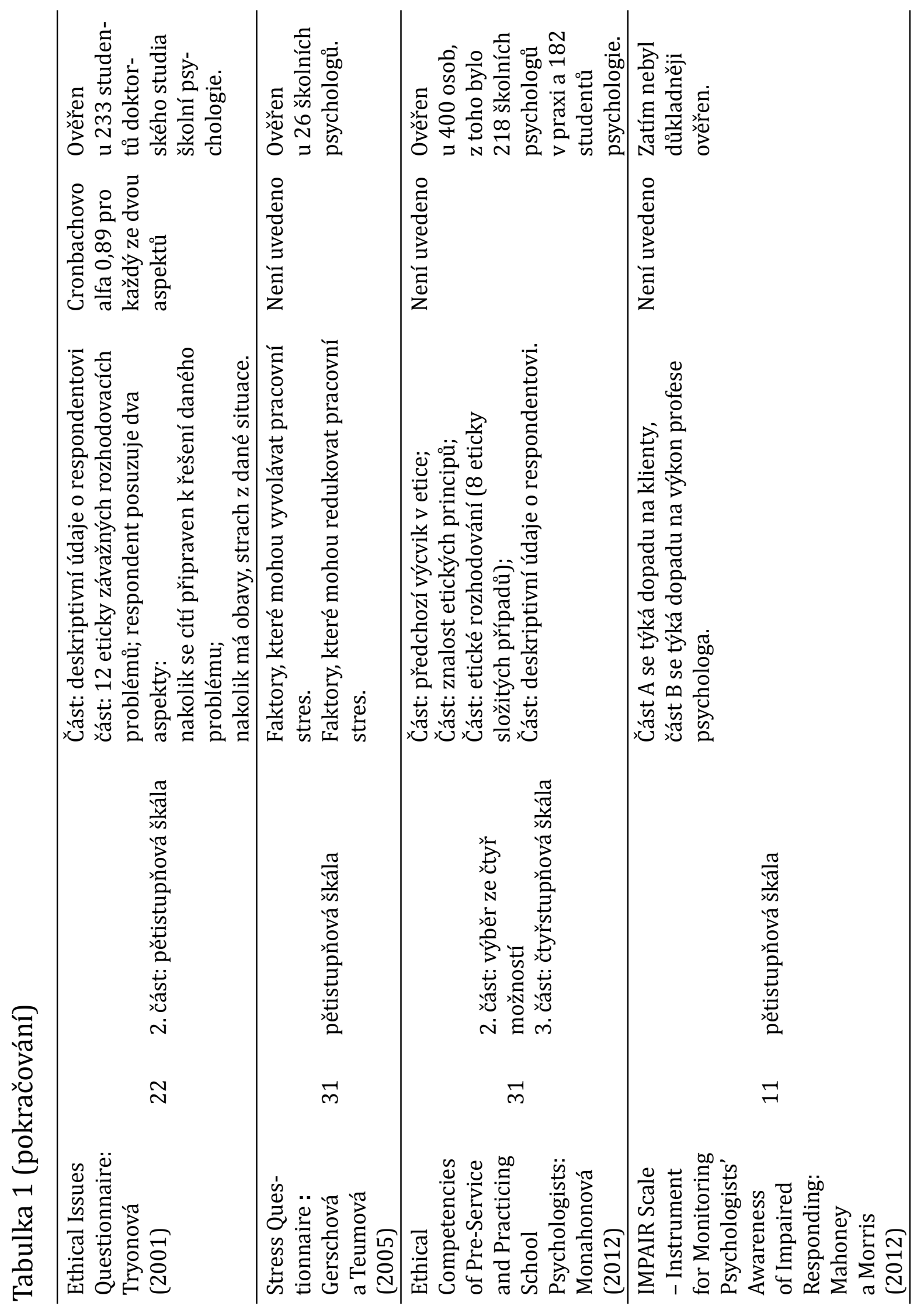




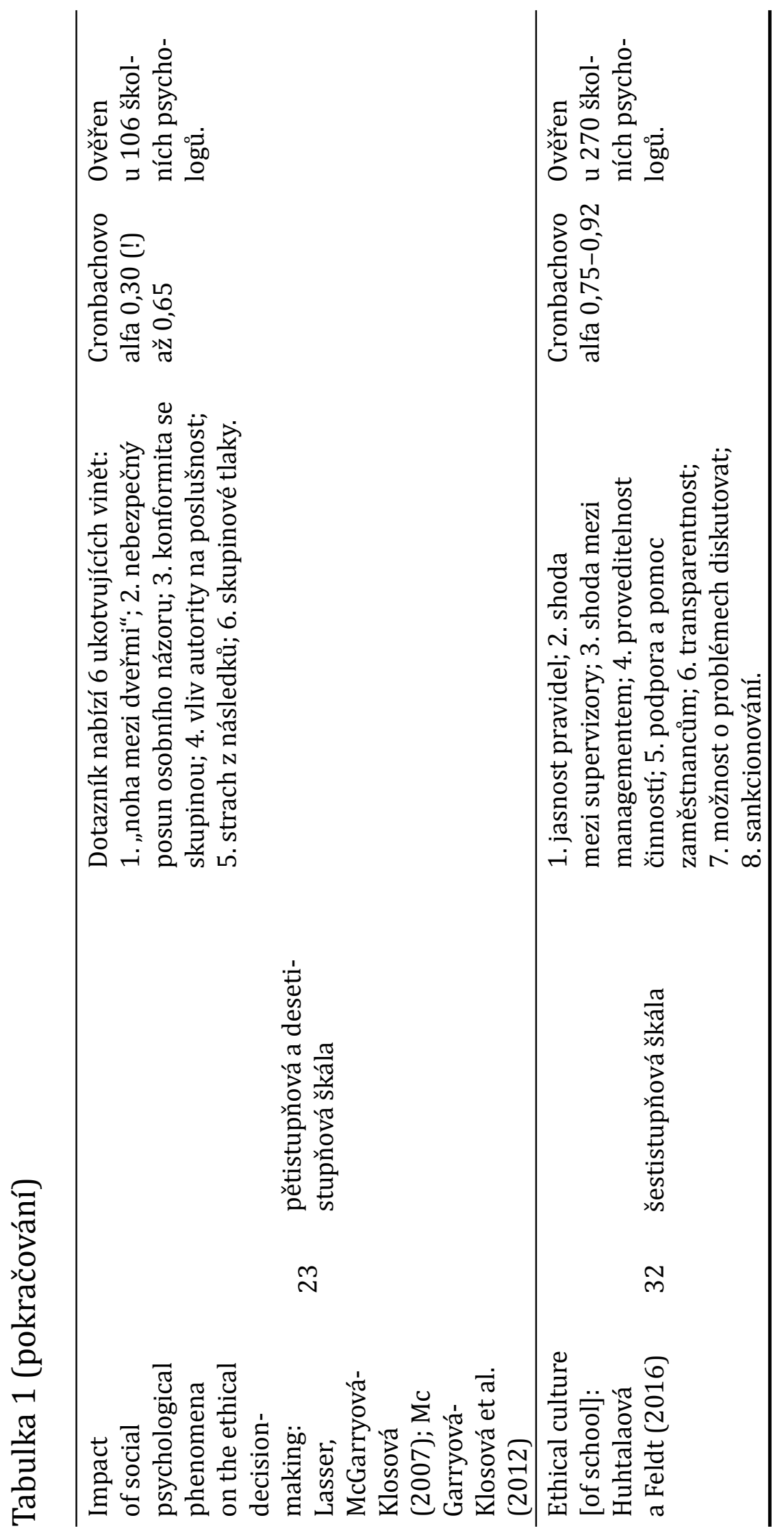

